\title{
EVALUASI SISTEM AKUNTANSI SIKLUS PENDAPATAN PADA PT. UNILAB PERDANA
}

\author{
Aries Wicaksono \\ Accounting and Finance Department, Faculty of Economics and Communication, BINUS University \\ Jln. K.H. Syahdan No.9, Palmerah, Jakarta Barat 11480 \\ aries.0202@gmail.com
}

\begin{abstract}
PT. Unilab Perdana is a company of environmental laboratories service provider. This study aims to evaluate the application of the accounting system in the revenue cycle, to identify the weaknesses and limitations of internal control, and to suggest improvements as needed. Research was carried out by using several methods. First, the method of data collection was conducted by the accounting system of internal control questionnaires revenue cycle. Second, the method of analysis was performed using the COSO internal control framework. The results obtained are accounting system in the revenue cycle applies to the company in general quite well, and accounting system in the company's revenue cycle has been partially implemented promptly and effectively, but there are still some things do not run effectively and efficiently.
\end{abstract}

Keywords: evaluation system, accounting, revenue cycle

\begin{abstract}
ABSTRAK
PT. Unilab Perdana merupakan perusahaan penyedia jasa laboratorium lingkungan hidup. Penelitian ini bertujuan untuk mengevaluasi penerapan sistem akuntansi dalam siklus pendapatan, mengidentifikasi kelemahan dan keterbatasan dari pengendalian internal, serta memberikan saran perbaikan yang diperlukan. Penelitian yang dilakukan dengan menggunakan beberapa metode. Pertama, metode pengumpulan data yang dilakukan dengan kuesioner pengendalian internal sistem akuntansi siklus pendapatan. Kedua, metode analisis yang dilakukan dengan menggunakan kerangka pengendalian internal COSO. Hasil penelitian diperoleh, yaitu sistem akuntansi dalam siklus pendapatan yang diterapkan pada perusahaan secara umum sudah baik; dan sistem akuntansi dalam siklus pendapatan yang diterapkan perusahaan sebagian sudah tepat dan efektif, tetapi masih ada beberapa hal yang belum berjalan secara efektif dan efisien.
\end{abstract}

Kata kunci: evaluasi sistem, akuntansi, siklus pendapatan 


\section{PENDAHULUAN}

Arus globalisasi yang telah berlangsung selama ini menuntut berbagai entitas bisnis untuk terus melakukan inovasi dan perbaikan dalam berbagai lini kegiatannya. Inovasi dan perbaikan tersebut harus dilakukan untuk menjaga agar kondisi entitas bisnis dapat terus meningkat dan memberikan nilai tambah. Dampak langsung yang dirasakan dari pertumbuhan usaha yang terus meningkat adalah dengan meningkatnya pertumbuhan omzet usaha dari tahun ke tahun mengikuti tren pertumbuhan ekonomi Indonesia yang positif. Peningkatan omzet usaha haruslah diikuti dengan peningkatan laba dari tahun ke tahun, oleh sebab itu segala aktivitas bisnis harus berjalan dengan efektif dan efisien.

Untuk menjaga pertumbuhan perusahaan terutama dalam hal peningkatan laba, maka suatu entitas bisnis harus fokus terhadap keberlangsungan usahanya. Keberlangsungan usaha yang positif dapat dicapai dengan membuat sistem operasional yang efektif dan efisien. Sistem operasional yang efektif dan efisien tersebut dapat ditunjang dengan prosedur yang baik serta penggunaan teknologi informasi dalam operasional bisnisnya. Prosedur dan teknologi informasi yang memadai dapat menjamin bahwa secara tidak langsung aktivitas bisnis yang dilakukan telah memenuhi unsur-unsur pengendalian internal yang efektif dan efisien.

Pengendalian internal dalam suatu perusahaan sangat memengaruhi keberlangsungan usaha suatu perusahaan. Pengendalian internal yang sesuai untuk diterapkan dalam suatu perusahaan sangat tegantung dari aktivitas bisnis suatu perusahaan. Pada dasarnya semua aktivitas dalam suatu perusahaan tidak bisa lepas dengan adanya pengendalian internal. Dengan adanya pengendalian internal yang baik, maka diharapkan dapat meminimalkan hal-hal yang dapat merugikan perusahaan. Oleh karena itu, untuk mendukung perusahaan untuk mencapai tujuan perusahaan diperlukan adanya pengelola atau manajemen yang dapat melakukan perencanaan, pengoordinasian serta pengendalian aktivitas yang baik serta dapat mendukung operasional bisnis perusahaan sehingga menjadi lebih efektif, efisien, dan transparan. Selain mempunyai pengendalian internal yang baik, untuk memastikan bahwa aktivitas pengendalian internal telah berjalan dengan baik, maka diperlukan pemeriksaan operasional atas aktivitas pengendalian internal yang ada. Sehingga prosedur serta kebijakan yang ada dalam pengendalian internal tersebut dapat mencapai tujuan yang dituju.

Salah satu siklus aktivtitas yang penting dalam suatu entitas bisnis adalah siklus pendapatan.Karena siklus pendapatan merupakan siklus yang terkait langsung dengan penerimaan atau revenue. Secara umum siklus pendapatan terdiri dari tiga komponen yaitu penjualan, pengelolaan piutang dan penerimaan kas. Ketiga aktivitas ini saling terkait sehingga jika salah satu diantaranya terjadi masalah maka secara langsung akan mengganggu yang lainnya. Untuk menjaga agar semua aktivitas dalam siklus pendapatan dapat berjalan dengan baik maka semua aktivitas harus berlangsung sesuai prosedur, dimana prosedur yang efektif dan efisien merupakan salah satu bentuk dari pengendalian internal yang baik.

PT. Unilab Perdana merupakan satu di antara beberapa perusahaan yang bergerak dalam bidang laboratorium lingkungan dan mendapat rekomendasi khusus dari kementerian lingkungan hidup. Jasa layanan yang diberikan oleh PT. Unilab Perdana meliputi pemeriksaan terhadap udara ambient dan lingkungan kerja, udara emisi sumber bergerak atau tidak bergerak (emisi cerobong dan emisi kendaraan bermotor), kualitas air (air minum, air bersih, air sungai, air limbah, air laut, dan air untuk industri), biota air (plankton dan benthos), sedimen atau sludge, serta kesehatan kerja (penerangan, kebisingan, kebauan, getaran, iklim kerja). Terhadap jasa yang diberikan oleh PT. Unilab Perdana, fungsi penjualan dilakukan secara tunai maupun kredit. Proporsi antara transaksi kredit dan tunai, lebih banyak dilakukan secara kredit. Proses pembayaran dilakukan baik dengan menggunakan uang tunai, cek atau bilyet giro serta transfer. Permasalahan yang selama ini dihadapi adalah adanya 
piutang tak tertagih, kemudian sering terjadinya manipulasi pemberian potongan harga atau diskon kepada klien. Oleh karena itu, diperlukan pengendalian atas proses tersebut sehingga dapat mengatasi atau meminimalkan risiko piutang tak tertagih yang ada.

Untuk mengetahui berbagai permasalahan yang ada pada siklus pendapatan PT. Unilab Perdana, maka dilakukan penelitian terhadap siklus pendapatan PT. Unilab Perdana. Adapun tujuan dilakukan penelitian adalah sebagai berikut: melakukan evaluasi atas pelaksanaan pengendalian internal pada PT. Unilab Perdana pada sistem akuntansi siklus pendapatan, apakah sudah berjalan dengan efektif dan efisien; melakukan evaluasi terhadap kegiatan operasional bisnis pada siklus pendapatam khususnya penjualan, piutang, dan penerimaan kas pada PT. Unilab Perdana apakah telah dilaksanakan sesuai prosedur dan kebijakan yang berlaku pada PT. Unilab Perdana; dan memberikan masukan dan saran kepada manajemen PT. Unilab Perdana atas kegiatan operasional bisnis pada siklus pendapatan sehingga dapat berjalan dengan lebih efektif dan efisien serta dapat meminimalkan risiko-risiko yang ada pada kegiatan operasional siklus pendapatan.

Selain tujuan dari penelitian yang dilakukan, ada manfaat dari yang diharapkan pada penelitian terhadap siklus akuntansi pendapatan PT. Unilab Perdana antara lain: bagi perusahaan, yaitu membantu perusahaan untuk mengetahui apakah pengendalian internal pada sistem akuntansi siklus pendapatan yang berlangsung selama ini sudah berjalan dengan baik serta dapat meningkatkan efektivitas dan efisiensi dari proses pengendalian internal yang berjalan. Bagi peneliti, memberikan gambaran bagi peneliti wawasan yang lebih luas mengenai proses pengendalian yang berjalan pada sistem akuntansi siklus pendapatan pada perusahaan khususnya perusahaan jasa layanan laboratorium lingkungan hidup. Bagi pihak lain, sebagai sarana yang bersifat informatif serta menjadi pengembangan pihak lain untuk melakukan penelitian yang lebih lanjut.

\section{Analisis Pustaka}

Berdasarkan literatur yang ada, pengertian sistem akuntansi menurut Bodnar \& Hopwood (2010), sistem akuntansi adalah metode dan catatan-catatan yang dibuat untuk mengidentifikasikan, mengumpulkan, menganalisis, mencatat, dan melaporkan transaksi-transaksi organisasi dan menyelenggarakan kewajiban dan aktiva yang berkaitan. Kemudian menurut Reeve, Warren, \& Duchac (2012) sistem akuntansi adalah metode dan prosedur untuk mengumpulkan, mengklasifikasikan, mengikhtisarkan, dan melaporkan informasi mengenai keuangan dan operasi usaha.

Berdasarkan pengertian sistem akuntansi di atas, maka dapat disimpulkan pengertian sistem akuntansi adalah metode, catatan-catatan, dan prosedur yang dibuat untuk mengidentifikasi, mengumpulkan, mengkikhtisarkan, mencatat, dan melaporkan transaksi-transaksi organisasi serta informasi mengenai keuangan dan operasi usaha.

Konsep dan pengertian pengendalian internal berdasarkan literatur yang ada yaitu menurut Bodnar \& Hopwood (2010), pengendalian internal adalah suatu proses yang dirancang untuk menyediakan keyakinan yang rasional atas tercapainya tujuan reliabilitas laporan keuangan, efektivitas dan efisiensi operasi perusahaan, dan kesesuaian organisasi dengan aturan regulasi yang ada. Sedangkan menurut Reeve, Warren, \& Duchac (2012), pengendalian internal adalah kebijakan dan prosedur yang melindungi asset dari penyalahgunaan, memastikan informasi bisnis yang ada akurat, serta memastikan bahwa hukum dan peraturan yang ada telah dipatuhi secara baik.

Berdasarkan pengertian di atas dapat disimpulkan bahwa pengendalian internal adalah suatu proses berupa kebijakan dan prosedur yang dirancang untuk memberikan keyakian yang rasional terhadap beberapa hal, antara lain: reliabilitas laporan keuangan, efektivitas dan efisiensi operasi perusahaan, aset yang ada terlindungi dari penyalahgunaan, informasi bisnis yang ada akurat, dan kesesuaian organisasi dengan aturan regulasi yang ada. 
Kerangka atau model pengendalian internal yang lazim digunakan yaitu model COSO (The Committee of Sponsoring Organization). Menurut Boynton dan Johnson (2006), COSO memiliki lima komponen atau unsur yang menunjang perusahaan untuk dapat mencapai tujuan yang telah ditetapkan antara lain: Lingkungan pengendalian (Control Environment) yang menetapkan suasana suatu organisasi, yang memengaruhi kesadaran akan pengendalian dari orang-orangnya; Penilaian risiko (Risk Assessment) merupakan pengidentifikasian dan analisis entitas mengenai risiko yang relevan terhadap pencapaian tujuan entitas, yang membentuk suatu dasar mengenai bagaimana risiko harus dikelola; Aktivitas pengendalian (Control Activities) yang merupakan prosedur yang membantu meyakinkan bahwa perintah manajemen telah dilaksanakan; Informasi dan komunikasi ( Information and Communication) yang merupakan pengidentifikasian, pengungkapan, dan pertukaran informasi dalam suatu bentuk dan kerangka waktu yang membuat orang mampu melaksanakan tanggung jawabnya; Pemantauan (Monitoring) yang merupakan suatu proses yang menilai kinerja pengendalian intern pada suatu waktu.

Untuk mengevaluasi suatu pengendalian internal menurut Agoes (2004) dalam organisasi dapat dilakukan dengan menggunakan beberapa instrumen antara lain: Internal Control Questionnaire (ICQ), instrumen ini biasanya digunakan oleh KAP untuk mengevaluasi pengendalian internal dari kliennya. Instrumen ini digunakan karena lebih sederhana dan praktis; Flowchart (bagan arus), instrumen ini biasanya digunakan untuk menggambarkan proses bisnis dalam suatu unit usaha. Auditor yang menggunakan flowchart merupakan auditor yang sudah terlatih, dengan menggunakan flowchart kelemahan-kelemahan yang ada lebih mudah untuk dianalisis; Uraian Cerita (narrative), instrumen ini biasanya digunakan untuk menggambarkan proses bisnis dari suatu organisasi yang memiliki proses bisnis yang sederhana.

Pengertian pendapatan menurut Ikatan Akuntan Indonesia dalam Pernyataan Standar Akuntansi Keuangan 23 (2011), pendapatan adalah arus masuk bruto dari manfaat ekonomi yang timbul dari aktivitas normal perusahaan selama suatu periode bila arus masuk tersebut menyebabkan kenaikan ekuitas yang berasal tidak dari penanam modal. Kemudian menurut Skousen, Stice dan Stice (2010) pendapatan adalah arus masuk atau penyelesaian kewajiban (atau kombinasi keduanya) dari pengiriman atau produksi barang, memberikan jasa atau melakukan aktivitas lain yang merupakan aktivitas utama atau aktivitas central yang sedang berlangsung. Dapat disimpulkan bahwa pendapatan adalah arus masuk yang menyebabkan peningkatan aset atau pengurangan kewajiban yang berasal dari aktivitas normal perusahaan sehingga menyebabkan perubahan ekuitas.

Konsep siklus pendapatan menurut Boynton dan Johnson (2006), siklus pendapatan (revenue cycle) perusahaan terdiri dari aktivitas-aktivitas yang berkaitan dengan pertukaran barang dan jasa dengan pelanggan dan penagihan pendapatan dalam bentuk kas. Siklus pendapatan adalah penjualan kredit (penjualan yang dilakukan dengan utang), penerimaan kas (penagihan piutang dan penjualan tunai), dan penyesuaian penjualan (potongan, retur penjualan dan pengurangan harga, serta piutang tak tertagih [penyisihan dan penghapusan]).

Sedangkan menurut Krismiaji (2010), siklus pendapatan adalah serangkaian kegiatan bisnis yang terjadi secara berulang dan kegiatan pengolahan informasi, yang berhubungan dengan penyerahan barang dan jasa kepada pelanggan dan penerimaan pembayaran kas dari penyerahan barang dan jasa tersebut.

Berdasarkan pengertian di atas, dapat disimpulkan bahwa siklus pendapatan mencakup fungsifungsi yang dibutuhkan untuk mengubah produk atau jasa menjadi pendapatan dari pelanggan. Fungsifungsi yang umum meliputi penawaran, penjualan, pengiriman barang, penagihan piutang sampai pengumpulan pembayaran kas dari hasil penjualan tersebut.

Konsep penjualan dan penerimaan kas menurut Romney (2003) bahwa fungsi penjualan dan penerimaan kas merupakan satu kesatuan dalam siklus pendapatan atau revenue cycle. Aktivitas yang masuk ke penjualan dapat dibagi dalam beberapa aktivitas yaitu menerima pesanan dari pelanggan, 
mengirimkan pesanan, menerima pembayaran, menyimpan pembayaran yang diterima, dan menyesuaikan perkiraan pelanggan. Untuk lebih jelasnya dapat digambarkan dalam tabel berikut ini.

Tabel 1 Tabel Aktivitas dalam Siklus Pendapatan

\begin{tabular}{ll}
\hline \multicolumn{1}{c}{ Aktivitas } & \multicolumn{1}{c}{ Dokumen Sumber } \\
\hline Menerima Pesanan Pelanggan & Permintaan Penjualan \\
Mengirimkan Pesanan & Bukti Pengiriman atau Surat Jalan \\
Menerima Pembayaran & Bukti Pembayaran \\
Menyimpan Pembayaran yang diterima & Slip deposit atau penyimpanan \\
Menyesuaikan akun pelanggan & Memo Kredit \\
\hline
\end{tabular}

Rangkuman kajian teoretis yang telah dianalisis dapat dilihat dalam tabel 2 sebagai berikut.

Tabel 2 Rangkuman Kajian Teoretis

\begin{tabular}{|c|c|c|c|}
\hline No & Sumber Teori & Penjelasan & Hubungan Penelitian \\
\hline 1 & $\begin{array}{l}\text { Bodnar dan } \\
\text { Hopwood } \\
(2010)\end{array}$ & $\begin{array}{l}\text { sistem akuntansi adalah metode dan } \\
\text { catatan-catatan yang dibuat untuk } \\
\text { mengidentifikasikan, mengumpulkan, } \\
\text { menganalisis, mencatat dan melaporkan } \\
\text { transaksi-transaksi organisasi dan } \\
\text { menyelenggarakan kewajiban dan aktiva } \\
\text { yang berkaitan }\end{array}$ & $\begin{array}{l}\text { Sistem akuntansi dapat berupa } \\
\text { metode atau prosedur dan } \\
\text { catatan-catatan atau dokumen. }\end{array}$ \\
\hline 2 & $\begin{array}{l}\text { Boynton dan } \\
\text { Johnson (2006) }\end{array}$ & $\begin{array}{l}\text { Komponen pengendalian internal } \\
\text { COSO terdiri dari Lingkungan } \\
\text { pengendalian, Penilaian Risiko, } \\
\text { Lingkungan pengendalian, Informasi dan } \\
\text { komunikasi, Pemantauan. }\end{array}$ & $\begin{array}{l}\text { Evaluasi pengendalian internal } \\
\text { dilakukan } \\
\text { Lingkungan berdasarkan } \\
\text { Penilaian Risiko, Lingkungan } \\
\text { pengendalian, Informasi dan } \\
\text { komunikasi, Pemantauan. }\end{array}$ \\
\hline 3. & $\begin{array}{l}\text { Ikatan Akuntan } \\
\text { Indonesia } \\
\text { (2011) }\end{array}$ & $\begin{array}{l}\text { Pendapatan adalah arus masuk bruto dari } \\
\text { manfaat ekonomi yang timbul dari } \\
\text { aktivitas normal perusahaan selama suatu } \\
\text { periode bila arus masuk tersebut } \\
\text { menyebabkan kenaikan ekuitas yang } \\
\text { berasal tidak dari penanam modal }\end{array}$ & $\begin{array}{l}\text { Pendapatan yang dimaksud } \\
\text { berupa arus masuk bruto dari } \\
\text { operasi bisnis perusahaan selama } \\
\text { suatu periode. }\end{array}$ \\
\hline 4 & Agoes (2004) & \begin{tabular}{lcr} 
Instrumen & untuk & \multicolumn{2}{r}{ mengevaluasi } \\
pengendalian & internal & dapat \\
menggunakan & Internal & Control \\
Questionnaire, & Flowchart, dan & Uraian \\
Cerita. & & \\
\end{tabular} & $\begin{array}{lll}\text { Evaluasi dilakukan } & \text { dengan } \\
\text { menggunakan Internal } & \text { Control } \\
\text { Questionnaire dan Uraian Cerita. }\end{array}$ \\
\hline 5 & $\begin{array}{l}\text { Boynton dan } \\
\text { Johnson (2006) }\end{array}$ & $\begin{array}{l}\text { Siklus pendapatan (revenue cycle) } \\
\text { perusahaan terdiri dari aktivitas-aktivitas } \\
\text { yang berkaitan dengan pertukaran barang } \\
\text { dan jasa dengan pelanggan dan } \\
\text { penagihan pendapatan dalam bentuk } \\
\text { kas.Siklus pendapatan adalah penjualan } \\
\text { kredit (penjualan yang dilakukan dengan } \\
\text { utang), penerimaan kas (penagihan } \\
\text { piutang dan penjualan tunai), dan } \\
\text { penyesuaian penjualan (potongan, retur } \\
\text { penjualan dan pengurangan harga, serta } \\
\text { piutang tak tertagih [penyisihan dan } \\
\text { penghapusan]). }\end{array}$ & $\begin{array}{l}\text { Evaluasi terhadap siklus } \\
\text { pendapatan dilakukan terhadap } \\
\text { komponen dari siklus pendapatan } \\
\text { yaitu penjualan kredit (penjualan } \\
\text { yang dilakukan dengan utang), } \\
\text { penerimaan kas (penagihan } \\
\text { piutang dan penjualan tunai), dan } \\
\text { penyesuaian penjualan (potongan, } \\
\text { retur penjualan dan pengurangan } \\
\text { harga, serta piutang tak tertagih } \\
\text { [penyisihan dan penghapusan]). }\end{array}$ \\
\hline
\end{tabular}




\section{METODE PENELITIAN}

Metode yang digunakan dalam penelitian ini adalah metode deskriptif dan wawancara. Penelitian deskriptif dilakukan dengan meneliti pengendalian internal yang berupa prosedur, kebijakan, dan aturan yang ada pada PT. Unilab Perdana kemudian mengevaluasinya berdasarkan permasalahan yang ada selama ini terjadi dengan menghubungkannya satu sama lain baik dari sisi prosedur, kebijakan serta aturan. Metode wawancara digunakan untuk memeperoleh gambaran langsung dari pelaku dalam sistem akuntansi siklus pendapaatan yang ada pada PT. Unilab Perdana. Dengan kedua metode tersebut dapat dihasilkan gambaran permaslaahan yang selama ini terjadi serta kendala-kendala untuk mengatasi permasalahan tersebut.

\section{HASIL DAN PEMBAHASAN}

\section{Hasil Kuesioner Pengendalian Internal dan Wawancara atas Sistem Akuntansi Siklus Pendapatan}

Dalam melakukan analisis dan evaluasi terhadap sistem akuntansi siklus pendapatan pada PT. Unilab Perdana dapat menggunakan beberapa instrumen antara lain berupa kuesioner, wawancara, dan flowchart. Instrumen-instrumen tersebut penting guna memperoleh gambaran dan menangkap bagaimana sistem akuntansi siklus pendapatan pada PT. Unilab Perdana selama ini. Baik kelebihankelebihan dan kelemahan-kelemahan yang ada selama ini berlangsung dapat diperoleh secara objektif.

Berdasarkan hasil kuesioner dan wawancara yang digunakan maka secara umum pengendalian internal atas sistem akuntansi siklus pendapatan pada PT. Unilab Perdana telah berjalan dengan cukup baik walaupun masih ada beberapa hal yang perlu menjadi perhatian bagi manajemen PT. Unilab Perdana. Hal tersebut dapat dilihat dari jawaban-jawaban yang ada pada kuesioner pengendalian internal. Hal-hal positif yang ada pada sistem akuntansi siklus pendapatan pada PT. Unilab Perdana, antara lain: Pertama, adanya pemisahan fungsi yang terkait dengan siklus pendapatan baik pada proses pemasaran, penerimaan kas maupun pengelolaan yang terkait dengan piutang terutama penagihan. Kedua, strategi yang terkait dengan penjualan atau pemasaran telah diketahui dengan baik oleh fungsi terkait dan diselaraskan dengan visi dan misi dari PT. Unilab Perdana. Ketiga, PT. Unilab Perdana sudah mempunyai Standar Operasional Prosedur (SOP) yang terkait dengan aktivitas dalam sistem akuntansi siklus pendapatan dan telah dikomunikasikan dengan seluruh pihak internal dan eksternal. Keempat, segala aktivitas yang terkait dalam sistem akuntansi siklus pendapatan pada PT. Unilab Perdana telah terdokumentasi dengan cermat, baik dokumen manual maupun dokumen yang terkomputerisasi. Kelima, proses pembaruan data penjualan pada proses penjualan berlangsung dengan baik, semua pengujian yang telah selesai dilakukan dan telah diterima pembayarannya secara keseluruhan langsung memperbarui data penerimaan kas. Keenam, PT. Unilab Perdana melakukan pengelolaan piutang dengan menggunakan kartu piutang secara komputerisasi dan secara manual sebagai back-up, kemudian dievaluasi dalam periode bulanan. Ketujuh, penerimaan pembayaran yang menggunakan cek dan bilyet giro dicatat terlebih dahulu ke dalam catatan tersendiri untuk mendata penerimaan menggunakan cek dan bilyet giro. Kedelapan, sebelum dilakukan pengujian dan pembuatan order, maka order atau permintaan pengujian dilakukan pengecekan ulang kepada konsumen baik melalui telepon ataupun email, hal ini dilakukan untuk menghindari kesalahan pengujian karena tidak sesuai dengan permintaan konsumen. Kesembilan, PT. Unilab Perdana melakukan rekonsiliasi antara saldo kas di bank dengan saldo kas di bank yang ada pada catatatan di perusahaan secara periodik untuk menghindari kesalahan pencatatan dan mendeteksi kecurangan yang mungkin terjadi. Kesepuluh, dalam proses pembuatan invoice, dilakukan pengecekan secara menyeluruh berdasarkan dokumen proses pengujian dan order confirmation, sehingga meminimalkan 
terjadinya kesalahan dalam hal invoicing atau penagihan. Kesebelas, PT. Unilab Perdana melakukan pengawasan terhadap semua piutang dengan membuat ukuran umur piutang dari masing-masing transaksi kredit, sehingga piutang yang akan jatuh tempo dapat terpantau dengan baik.

Kelemahan-kelemahan yang dapat ditangkap dalam kuesioner pengendalian internal sistem akuntansi siklus pendapatan pada PT. Unilab Perdana adalah sebagai berikut. Pertama, pemberian diskon yang tidak diatur dengan jelas pada peraturan perusahaan, walaupun dalam pemberian diskon tersebut harus melalui proses otorisasi dari kepala marketing dan divisi akuntansi. Hal ini dapat memberikan ruang kecurangan bagi divisi marketing untuk bermain di dalam persentase diskon. Kedua, tidak adanya prosedur backup terhadap transaksi penjualan. Data hanya disimpan dalam storage server tanpa ada prosedur backup tambahan. Hal ini dapat menyebabkan kehilangan data jika tidak ada backup tambahan. Selain itu backup dalam dokumen manual tidak mencakup semua aktivitas pada siklus pendapatan PT. Unilab Perdana. Ketiga, adanya intervensi dari pihak komisaris dalam manajemen, sampai pelaksanaan aktivitas penjualan sehari-hari. Hal ini menyebabkan rentang kendali manajemen yang tidak berjalan dengan fungsi yang seharusnya. Keempat, tidak ada pencadangan terhadap piutang tak tertagih, sehingga risiko atas piutang tak tertagih menjadi lebih tinggi. Hal tersebut didukung dengan adanya fakta bahwa adanya piutang tak tertagih dari tahun ke tahun. Kelima, tidak ada prosedur batasan pemberian kredit (credit limit), sehingga dapat meningkatkan risiko adanya piutang tak tertagih. Hal tersebut terus berlangsung karena divisi marketing diberikan target yang terus meningkat dari tahun ke tahun. Keenam, perusahaan tidak mengirimkan surat pemberitahuan utang kepada konsumen secara periodik, proses komunikasi hanya dilakukan menggunakan telepon. Ketujuh, adanya piutang tak tertagih salah satu hal penyebabnya adalah PT. Unilab Perdana berhubungan dengan konsultan lingkungan hidup, tidak secara langsung dengan perusahaan yang melakukan pengujian. Suatu waktu konsultan lingkungan hidup tersebut tidak beroperasi lagi, maka PT. Unilab Perdana kesulitan untuk menagihnya.

\section{Evaluasi atas Sistem Akuntansi Siklus Pendapatan pada PT. Unilab Perdana}

Berdasarkan hasil kuesioner pengendalian internal dan wawancara yang telah dilakukan secara umum pengendalian internal sudah ada pada sistem akuntansi siklus pendapatan pada PT. Unilab Perdana tetapi masih ada kelemahan-kelemahan yang masih berlangsung pada sistem akuntansi siklus pendapatan pada PT. Unilab Perdana. Sedangkan perlu menjadi perhatian bahwa siklus pendapatan pada suatu entitas bisnis merupakan bagian penting dalam berjalannya roda operasional perusahaaan, selain itu juga menjadi titik perhatian utama karena terkait langsung dengan penerimaan atau pendapatan perusahaan.

Hal utama yang menjadi perhatian dalam pengendalian internal sistem akuntansi siklus pendapatan pada PT. Unilab Perdana adalah adanya piutang tak tertagih, ketidakjelasan dalam hal pemberian diskon,tidak adanya prosedur batasan kredit karena menjadi masalah bagi target divisi marketing dan adanya intervensi dari komisaris terhadap operasional bisnis sehari-hari. Hal tersebut menjadi perhatian khusus karena sangat berkaitan dengan operasional bisnis sehari-hari dan perlu dicatat bahwa biaya investasi peralatan dalam laboratorium lingkungan hidup tidaklah sedikit.

Evaluasi atas pengendalian internal sistem akuntansi siklus pendapatan pada PT. Unilab Perdana dilakukan dengan menggunakan kerangka kerja COSO yang terdiri dari lima komponen. Berikut adalah pembahasan secara masing-masing komponen pada kerangka kerja pengendalian internal COSO.

\section{Lingkungan Pengendalian (Control Environment)}

Ada beberapa hal yang menjadi perhatian dalam komponen lingkungan pengendalian yaitu integritas dan etika, gaya manajemen, struktur organisasi dan pemisahan wewenang, serta kebijakan terhadap sumber daya manusia. Keempat hal tersebut merupakan hal yang saling terkait satu sama lain, sehingga saling memengaruhi. 
Integritas dan etika merupakan hal yang sangat dijaga oleh PT. Unilab Perdana. Manajemen selalu menjelaskan pentingnya integritas dan etika. Integritas dan etika diakomodasi di dalam tata laksana kantor yang mengatur semua aturan kantor dan karyawan. Tata laksana kantor selalu dikomunikasikan oleh manajemen kepada semua karyawan, pada setiap program pelatihan karyawan hal tersebut selalu disosialisasikan. Kemudian ketika orientasi penerimaan karyawan baru juga harus mengikuti sosialisasi Tata Laksana Kator. Dalam hal pemasaran atau penjualan, karyawan pada divisi marketing dilarang untuk menerima pemberian dalam bentuk apa pun dari konsumen. Manajemen memberikan bonus bagi divisi marketing jika mencapai kinerja yang ditargetkan. Namun dalam pelaksanaannya, masih ditemukan permainan dalam hal pemberian diskon, oleh karena itu perlu diberikan aturan baku dalam pemberian diskon terutama dalam hal penentuan persentase diskon.

Dalam hal gaya manajemen dalam pengelolaan organisasi sudah cukup baik. Manajemen bersifat akomodatif dan memberikan kesempatan bagi seluruh karyawan untuk menyuarakan aspirasi baik dalam hal kesejahteraan maupun dalam hal pekerjaan. Manajemen melakukan pertemuan manajemen dengan seluruh karyawan setiap tiga bulan, untuk menyerap aspirasi yang dimiliki oleh karyawan. Manajemen juga melakukan rekreasi bersama keluarga setiap tahun guna menjaga keakraban dan soliditas dalam internal PT. Unilab Perdana.

Struktur organisasi dan pembagian wewenang pada PT. Unilab Perdana sudah ada dan berjalan walaupun ada suatu masalah yang ditemukan, yaitu adanya intervensi komisaris dalam hal operasional bisnis perusahaan secara langsung. Hal ini dapat mengganggu rentang kendali dalam operasional bisnis perusahan karena tidak sesuai dengan struktur organisasi, pembagian tugas dan wewenang yang telah diatur dalam Standar Operasional Prosedur (SOP). Untuk itu diperlukan komitmen dari seluruh manajemen dan karyawan tidak terbatas untuk komisaris, dalam hal wewenang dan fungsi yang dimiliki sehingga tidak memicu konflik yang tidak diinginkan dalam organisasi PT. Unilab Perdana.

Pengelolaan sumber daya manusia pada PT. Unilab Perdana menjadi fokus perusahaan, karena keterampilan dan skill dalam proses pengujian laboratorium diperlukan keahlian khusus. Semua karyawan di bagian laboratorium pengujian diberikan pelatihan dan sertifikasi untuk dapat melakukan pengujian laboratorium secara profesional. Tidak hanya bagian laboratorium pengujian, karyawan di divisi lain juga diwajibkan pelatihan yang diselenggarakan oleh PT. Unilab Perdana. Selain pelatihan, manajemen juga memberikan berbagai fasilitas untuk karyawan agar karyawan dapat bekerja dengan nyaman di PT. Unilab Perdana.

\section{Penilaian Risiko (Risk Assessment)}

Penilaian risiko merupakan hal yang sangat penting, karena usaha untuk meminimalkan terjadinya kecurangan dan ketidakefisiensian dari operasional bisnis perusahaan sangat tergantung dari kemampuan perusahaan melakukan mitigasi atas risiko yang ada pada sistem akuntansi siklus pendapatan. Dari fakta yang didapatkan selama ini, manajemen belum dapat memitigasi risiko dengan baik karena selama ini masih ada masalah yang terjadi yaitu pemberian diskon yang tidak tertib dan transparan sehingga dapat mengurangi penerimaan atau pendapatan bagi PT. Unilab Perdana. Intervensi langsung terhadap operasional bisnis perusahaan sehingga dapat membuat suasana yang tidak nyaman dalam internal PT. Unilab Perdana, piutang tak tertagih yang ada dari tahun ke tahun sehingga mengurangi pendapatan yang seharus diperoleh perusahaaan.

\section{Aktivitas Pengendalian (Control Activities)}

Akivitas pengendalian terkait dengan mekanisme yang menjaga agar semua aktivitas bisnis PT. Unilab Perdana berjalan sesuai dengan aturan yang telah ditentukan. Untuk memastikan bahwa aktivitas bisnis perusahaan telah dilakukan sesuai dengan aturan, maka perusahaan menerapkan pengendalian yang bersifat kebijakan, aturan dan prosedur, kemudian pengendalian yang bersifat fisik 
secara langsung. Pemisahan wewenang dan fungsi merupakan salah satu bentuk pengendalian yang diterapkan PT. Unilab Perdana, pemisahan fungsi dan wewenang tersebut dapat dilihat dalam struktur organisasi yang ada pada PT. Unilab Perdana.

Pada fungsi siklus pendapatan pengendalian dari pemisahan fungsi dan wewenang terlihat dari adanya pemisahan fungsi terkait dengan penjualan, penerimaan kas dan pengelolaan piutang. Ketiga fungsi tersebut dipisah untuk meminimalkan kecurangan yang kemungkinan dapat terjadi. Kemudian adanya otorisasi dalam suatu aktivitas juga menjadi salah satu pengendalian internal yang diterapkan oleh PT. Unilab Perdana. Otorisasasi dilakukan ketika perusahaan memberikan fasilitas kredit bagi klien atau customer yang akan melakukan transaksi kredit dengan PT. Unilab Perdana. Kemudian ketika akan melakukan penagihan maka di dalam prosedur PT. Unilab Perdana ada otorisasi dari deputi manajer keuangan, hal tersebut merupakan salah satu bentuk pengendalian internal agar tidak terjadi kesalahan dalam penagihan. Tetapi fakta mengenai adanya intervensi dari komisaris mengenai proses pada siklus pendapatan memberikan arti bahwa pemisahan wewenang dan fungsi ini tidak sepenuhnya berjalan dengan baik.

Pengendalian internal yang bersifat pengendalian fisik terhadap aset yang dimiliki oleh PT. Unilab Perdana. Karena banyak aset yang bersifat bahan kimia yang digunakan untuk proses pengujian laboratorium dan nilainya material, kemudian peralatan laboratorium yang nilainya juga material, PT. Unilab membuat mekanisme membuat kartu persediaan di gudang bahan kimia dan peralatan uji. PT. Unilab Perdana juga memasang CCTV di semua ruangan kerja untuk memantau dan meminimalkan terjadinya kecurangan yang mungkin terjadi pada semua aktivitas bisnis yang berlangsung di PT. Unilab perdana sehari-hari.

\section{Informasi dan Komunikasi (Information and Communication)}

Hal mengenai informasi dalam sistem akuntansi siklus pendapatan pada PT. Unilab Perdana, terkait semua proses dari pemasaran atau penjualan kemudian pengelolaan piutang dan penerimaan kas semua sudah menggunakan sistem yang terkomputerisasi. Aturan pelaporan yang jelas juga telah ditetapkan oleh PT. Unilab Perdana. Ada laporan yang sifatnya mingguan, bulanan dan tiga bulanan. Laporan tersebut mengenai aktivitas dalam sistem akuntansi siklus pendapatan pada PT. Unilab Perdana.

Semua laporan tersebut dikomunikasikan sesuai dengan jenjang organisasi. Kemudian digunakan sebagai bahan pertemuan yang terkait dengan kinerja pada siklus pendapatan di PT. Unilab Perdana. Hasil dari laporan tersebut juga penting digunakan sebagai bahan pengambilan kebijakan serta keputusan yang terkait dengan sistem akuntansi siklus pendapatan pada PT. Unilab Perdana. Sehingga dapat diambil kesimpulan betapa pentingnya informasi dalam perusahaan karena kualitas dari pelaporan yang dibuat sangat memengaruhi kualitas dari kebijakan dan keputusan yang diambil oleh manajemen PT. Unilab Perdana.

\section{Pemantauan (Monitoring)}

Pemantauan dilakukan di semua level baik level bawah, menengah, dan atas di PT. Unilab. Kemudian pemantauan atas kinerja tersebut dilakukan secara berjenjang dari satu level ke level di atasnya dalam organisasi. Untuk menjaga hasil objektifitas dalam pemberian nilai kinerja dari masingmasing personal yang diawasi, maka pemantauan tidak hanya bersifat vertikal dalam organisasi tetapi juga horizontal. Maksudnya, sesama karyawan yang mempunyai level yang sama dalam organisasi juga saling mengawasi satu sama lain. Sehingga setidaknya didapatkan dua manfaat yaitu penilaian kinerja yang lebih objektif dan meminimalkan terjadinya kecurangan yang mungkin terjadi. 


\section{SIMPULAN}

Berdasarkan pembahasan dan evaluasi terhadap sistem akuntansi siklus pendapatan pada PT. Unilab Perdana, dapat diambil kesimpulan bahwa sudah ada kerangka pengendalian internal yang diterapkan dalam PT. Unilab Perdana. Akan tetapi, dalam pelaksanaan ada beberapa yang belum sesuai aturan dan masih ada yang perlu perbaikan baik secara kebijakan maupun pelaksanaan dari sistem akuntansi siklus pendapatan pada PT. Unilab Perdana. Beberapa hal penting yang menjadi fokus perbaikan juga harus menjadi perhatian bagi pihak manajemen PT. Unilab Perdana.

Hal penting yang menjadi fokus perhatian dari manajemen terkait dengan efektivitas pelaksanaan prosedur dan kebijakan yang telah dibuat. Tidak boleh ada lagi fungsi dalam sistem akuntansi siklus pendapatan pada PT. Unilab Perdana yang menjalankan fungsi yang tidak seharusnya dijalankan oleh masing-masing fungsi tersebut. Jika hal tersebut terus berjalan, kerangka pengendalian internal yang telah dirancang akan menjadi percuma.

Perbaikan lain adalah diperlukan prosedur baku dalam standar diskon, karena otorisasi saja belum cukup selama staf pada divisi marketing bebas menentukan diskon meskipun telah diberikan batasan maksimal diskon 20\%. Selain itu, pengetatan dalam batasan kredit yang diberikan juga harus menjadi hal utama. Karena selama tidak ada batasan kredit yang diberikan kepada klien, akan semakin meningkatkan kemungkinan piutang tak tertagih jika tidak didukung oleh sistem pengendalian piutang yang baik.

\section{DAFTAR PUSTAKA}

Agoes, S. (2004). Auditing : Pemeriksaan Akuntan oleh Akuntan Publik. Jakarta: Lembaga Penerbit Fakultas Ekonomi Universitas Indonesia.

Bonar, G. H., \& Hopwood,W. S. (2010). Accounting Information Systems. US: Pearson Education.

Boynton,W. C., \& Johnson, R. N. (2006). Modern Auditing: Assurance Services and The Integrity of Financial Reporting. US: John Wiley \& Sons.

Ikatan Akuntan Indonesia. (2011). Pernyataan Standar Akuntansi Keuangan. Jakrta: Salemba Empat.

Krismiaji.(2010). Sistem Informasi Akuntansi.Yogyakarta: Unit Penerbitan dan Percetakan sekolah Tinggi Ilmu Manajemen YKPN.

Reeve, J. M., Warren, C. S., Duchac, J. E. (2012). Principles of Accounting. South-Western: Cengage Learning.

Romney, M. B, Steinbart, P. J. (2003). Accounting Information System. US: Prentice Hall.

Stice, E. K., Stice, J. D., Skousen, K. F. (2010). Intermediate Accouting. South-Western, China: Cengage Learning. 